\title{
Industrial-scale plantlet production by seed priming and nursery tray seeding method in Sida hermaphrodita L. Rushby
}

\author{
Kurucz E. 1,*, El-Ramady H. R., ${ }^{1,3}$ \& Fári M. G. ${ }^{1,2}$ \\ ${ }^{1}$ Department of Plant Biotechnology, University of Debrecen AGTC, Debrecen \\ ${ }^{2}$ Ereky Foundation, Hungary, Soil and Water Sciences Department, Faculty of Agriculture \\ ${ }^{3}$ Kafrelsheikh University, Kafr El-Sheikh, Egypt \\ *Corresponding authore-mail: era.kurucz@gmail.com
}

\begin{abstract}
Virginia mallow (Sida hermephrodita Rushby), Malvaceae family, is a perspective perennial herb able to yield a biomass crop through the last two decades. In our previous studies, we examined two factors relating to seed germination percent and seed germination power during our research: the influence of hot water treatment and the effect of exogenous or endogenous infection of seed. Following these recognition we modified our technique, in such a way that we fractionated the seeds based on their fresh weight / or relative density before we carried out the treatment. When we filtered the floating seeds on the surface of water, the hot water treatment was performed considerably better on the sink seeds after separation. Therefore, by this special priming process we were able to reach $80 \%$ germination capacity of Virgina mallow seeds under laboratory conditions $\left(26^{\circ} \mathrm{C}\right.$ without illumination). From all nurseries tray methods preliminary results, it is clear that, Sida seeds, which were treated with these methods, gave the best growing rate for industrial uses.
\end{abstract}

Key words: Sida hermaphrodita Rushby; seed priming; plantlet production; Nursery-in-Tray Method

\section{Introduction}

The European Commission presented an action plan to reduce the insecurity of investors by evaluating the physical and economic availability of different biomass types, including wood and wood residues, waste and agricultural crops, and by determining priorities regarding the biomass types in use and ways of developing them, as well as by pointing out measures to be taken in order to enhance this. This action plan is also connected with consumer information campaigns about the benefits of biomass and bioenergy (Pszczótkowska et al., 2012).

It is well documented that, biomass is a renewable resource and refers to any material having recent biological origin, such as plant materials, agricultural crops, and even animal manure. Biomass can be defined as any plant-derived organic matter (Kaur et al., 2014). Biomass available for energy on a sustainable basis includes herbaceous and woody energy crops, agricultural food and feed crops, agricultural crop wastes and residues, wood wastes and residues, aquatic plants, and other waste materials including some municipal wastes. Furthermore, biomass is a very heterogeneous and chemically complex renewable resource. Finally, owing to its natural abundance, sustainability, and often low cost, biomass is a potential alternative to nonrenewable energy sources for production of chemicals (Kaur et al., 2014).

In recent last years there has been numerous research conducted on plants of large energy biomass production potential. Non-food perennial species of agricultural plants are especially interested in, Amur silvergrass (Miscanthus sacchariflorus L.), Big bluestem (Andropogon gerardii Vitman), Jerusalem artichoke (Helianthus tuberosus L.), Miscanthus (Miscanthus gigantheus), Prairie cordgrass (Spartina pectinata Bosc.), Switchgrass (Panicum virgatum L., Poiret), Virginia mallow (Sida hermaphrodita L. Rusby) and Willow (Salix sp.), as reviewed by Borkowska et al.,(2009).

Sida has been introduced to Europe during the 1930s (USSR, Ukraine) as a potential fiber plant. It has been studied as a potential biomass species in Poland from the 1950s and in Hungary from the late 1970s by Prof. Kovács Zoltán (Fári, 2014). Commercial varieties of Sida have not been produced, although it may have serious economic impact in the future as biomass plant, animal food and even as a potential vegetable for human consumption, honey plant, pulp, or phytoremediation purposes (Fári, 2014).

From 2003 we have studied our Sida germplasm collection at Future Biomass Plants Garden of the Centre of Agriculture, University of Debrecen (Debrecen, Hungary). The first observation indicated that Sida population obtained from natural stands can be an excellent starting material for a complex breeding program in order to improve the germination rate, to increase biomass production by poliploidization as well as to develop in vitro propagation, genetic transformation procedures for further molecular breeding (Kurucz et al., 2012). Sida hermaphrodita has 
some advantages including high potential yield of a dry matter crop; low moisture of harvested biomass (15-30\%); harvesting during the heating season from late autumn to spring; low fertilizer requirements; low ash content (ca. 2\%); the possibility of using conventional agricultural machinery for sowing, cultivation, and harvesting of biomass; the possibility of growing on vulnerable soils (even the V-class); the possibility of fertilizing with sewage sludge and other organic composts. On the other hand, disadvantages of Sida hermaphrodita include low germination potential (3-10\%); sensitivity of weeds in the first year of cultivation; no yield in first and second year of cultivation (Kurucz et al., 2012).

Hard seeds are common in a number of species in the Malvaceae family (Spooner, 1985). S. hermaphrodita is known in the literature as a plant with low seed germination potential. In the case of Sida spinosa L., it has been shown that water impermeability of the seeds is partly explicable due to a compact layer of integumentary palisade cells. A similar layer of cells occurs in seeds of Sida hermaphrodita L, which dormancy can be stopped by hot water treatment (Chudzik et al., 2010). Spooner et al. (1985) founded that the low germination percent obtained apparently due to his failure to scarify the seeds. In Europe, many authors have dealt with this problem because of possible industrial uses of this plant (Chudzik et al., 2010). For this reason, in Europe this plant is reproduced mainly in a vegetative way from root cuttings. In addition if one tries to establish Sida plantation by seeds, in the first period the very slowly developing seedlings will be inhibited by the weeds. Hence, Nursery Techniques could be used involving seed priming methods, and raising seedlings. Several new techniques are now available, which are cheap and able to eliminate the first growing period hardness. These new techniques are useful in increasing the success rate of grafts and rooting of the cutting; increasing seedling vigour; reducing transplanting shock and generally reducing the quantum of manual work. Unavoidable the biotechnology and environmental research of Sida, which is in a base stage of domestication, before it is, took into cultivation for industrial biomass purposes.

The aim of this study is to detect and solve all of the problems linked closely to the propagation and growing of Sida hermaphrodita. Our research program is focused on perennial mallow species which are not only ornamentals but the same time they are large biomass producing potential energy plants. The aim of our present investigation was (1) to analyse the effect of two steps priming methods and (2) to study a new nursery method which can suitable for Sida hermaphrodita propagation for industrial uses.

\section{Materials and methods}

\section{Collecting of seed samples}

Germination and viability tests were conducted during March 2013 on seeds of Sida collected from our Plants for the Future Biomass Experimental Garden in the spring of
2012. Mature dry fruit clusters were manually harvested and threshed (Kurucz et al., 2012).

\section{Seed pretreatment by Floated Seed Priming Technique (FSPT)}

It could be found detailed information about Hot Water pre-treatment Method (HWT) and its influence on germination and contamination rate in our previous study (Kurucz et al., 2013). This HWT protocol was complemented with a simple seed priming step to fractionate them based on their specific weight, and or imbibition / permeability characteristic. First, before we put the samples into heated water, the seeds were immersed into distilled water of 23-25 ${ }^{\circ} \mathrm{C}$ for 30 minutes. After this step, the hot water treatment was performed on the dipped seeds followed separation. The sink but not treated seeds were considered as control. These FSTP seeds were sown on wetted filter papers and put into Petri dishes for $26{ }^{\circ} \mathrm{C}$ without lighting (Kurucz et al., 2012). Seedling counts were performed at 3 and 6 days later and total percent of germination. During this study we observed fungal contamination in the seeds. The infected seeds could not germinate, and different mycelia types were observed in the seed surface or white/grey mold. The contamination rate was calculated for each treatment.

\section{Plantlet production from primed Sida seeds in nursery trays}

The treated seeds, which used in the previous treatment description (FSPT), were carried to the industrial ornamental and vegetables plant nursery (KITE Ltd, Derecske) in order to develop and to examine the nurse tray method. We used usual (126 cell/tray, $60 \mathrm{~cm}^{3}$ each cell) plastic nursery trays which are used in cabbage and green pepper plantlet production. Because, we had not any information about the germination ratio of the pre-treated seeds out of the laboratory conditions, and the aim of to support the effective surface utilization, we put two seeds in each cell by hand. The date of sowing was at $27-28^{\text {th }}$ on March, 2013. After this the trays were placed in an industrial-scale seed germination chamber, in which was $28^{\circ} \mathrm{C}$ and $90-99 \%$ relative humidity. After two days the trays was removed to the $50 \mathrm{~m} \times 9 \mathrm{~m}$ special plastic tunnel, under same conditions (plant protection, bottom pipe-heating, fertigation and irrigation) like white cabbage, broccoli and kohlrabi (Brassica oleracea). We observed fast longitudinal extension which may caused by the unfavourable light conditions. Because of this phenomenon we cut back the Sida stems $20 \mathrm{~cm}$ above the root collar. Two times during the experiment (30.04. and 17.05.2013) we kept count of germinated seedlings in ten trays witch was in different position (outer, inner) and was chosen randomly. In the same time, we measured the root and shoot fresh and dry weight, separated the cells or 'root balls' according to how many seedlings (one or two) those contain (we measured 20 root balls with one, and 20 root balls with two plants). In total we sowed the pre-treated primed Sida seeds into 160 pieces nursery trays. 


\section{Results and discussion}

\section{The effect of FSPT on the Sida germination pattern}

Table 1 and Fig. 1 show the seed germination and infection percent in water fractionated (dipped and supernatants) and control samples. In this FSPT treatment, it is found that $80^{\circ} \mathrm{C}$ is the most effective priming temperature. On the basis of our previous data, it could be concluded that, we were able dramatically to increase the germination percent from $4.67 \%$ to $80 \%$ in average, and we also were able decrease dramatically or entirely eliminate the seed contaminations from $44.3 \%$ to $0 \%$, under laboratory conditions (Fig. 1 and Table 1). The control seeds germination and infection ratio was accounted separately (earlier), thus the control results (3 repetitions both season) were summarized and Standard deviation (SD) was calculated from these results. This could be the reason, which caused the high SD in the Table 1.

\section{Plantlet production in nursery trays from primed Sida seeds}

Table 2 shows the number of seedlings, the average germination rate, single and double plant ratio in the nursery trays. Every tray contained 252 seeds; two seeds in each cell. It is clear that, the Standard deviation (SD) is quite high mainly in the number of seedling/ tray, which can cause by the cheap industrial plant nursery circumstances. We meet some irregularities which are normal in this industrial dimension. For example some spray heads broke down which caused some irrigation disorders, in this way in some tray many of the plant were withered meanwhile some trays were over irrigated. Apart from these conditions we can clearly see that the average germination rate was around $50 \%$, which are more than tenfold than the fresh seeds germination rate. The ratio of root balls which contained two plants were low, $23.26 \%$ considering the whole seedlings. These plants are healthy and easy to separate it, therefore these plants are convenient for the future propagation starting material. HWT priming

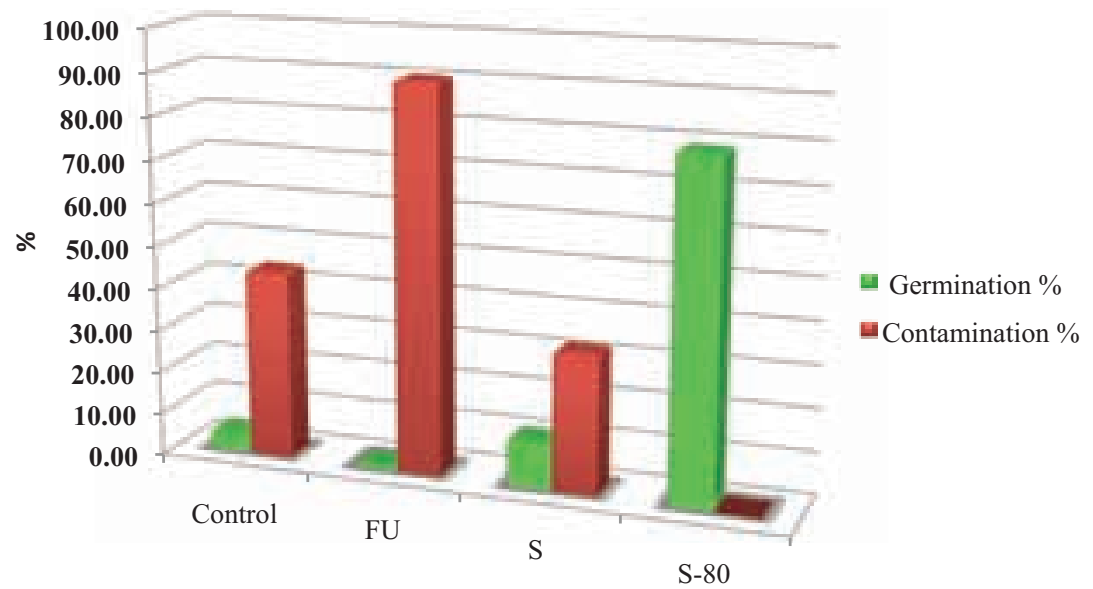

Figure 1. Germination and contamination pattern of water-fractionated seeds with or without

FU: Floated seeds/supernatant fraction S-80: sunk seeds/ imbibed fraction under $80{ }^{\circ} \mathrm{C}$ hot water treatment; S: sunk but not treated seeds; Control: not fractionated, soaked in destillited water in room temperatupe

Table 1. Germination and contamination pattern of water-fractionated seeds with or without HWT priming (50 pcs seeds per each treatment)

\begin{tabular}{|l|c|c|c|c|}
\hline Treatment & $\begin{array}{c}\text { Mean of } \\
\text { Germinated } \\
\text { seeds (pcs) }\end{array}$ & $\begin{array}{c}\text { Mean } \\
\text { of Contaminated } \\
\text { seeds (pcs) }\end{array}$ & $\begin{array}{c}\text { Germination } \\
\%\end{array}$ & $\begin{array}{c}\text { Contamination } \\
\%\end{array}$ \\
\hline Control & $2,33 \pm 1,53$ & $22,17 \pm 9,89$ & $4,67 \pm 2,42$ & $44,33 \pm 21,78$ \\
\hline FU & $0,33 \pm 0,58$ & $45,33 \pm 1,53$ & $0,67 \pm 1,15$ & $90,67 \pm 3,06$ \\
\hline S & $5,67 \pm 2,31$ & $16,33 \pm 2,52$ & $11,33 \pm 4,62$ & $32,67 \pm 5,03$ \\
\hline S-80 & $39,67 \pm 3,51$ & $0,00 \pm 0,00$ & $79,33 \pm 7,02$ & $0,00 \pm 0,00$ \\
\hline
\end{tabular}

$\pm \mathrm{SD}(\mathrm{n}=3)(\mathrm{P} \leq 0,05)$

Table 2. Preliminary effectiveness rates of Sida h. neurs in tray method

\begin{tabular}{|c|c|c|c|c|c|c|}
\hline & $\begin{array}{l}\text { Single } \\
\text { plants }\end{array}$ & $\begin{array}{c}\text { Double } \\
\text { plants }\end{array}$ & $\begin{array}{c}\text { Seedlings/ } \\
\text { tray }\end{array}$ & $\begin{array}{c}\text { Germination } \\
\text { rate } \%\end{array}$ & $\begin{array}{c}\text { Double rate } \\
(\%)\end{array}$ & $\begin{array}{c}\text { Single rate } \\
(\%)\end{array}$ \\
\hline Mean & $\begin{array}{c}106,75 \pm \\
23,14\end{array}$ & $\begin{array}{c}34,92 \pm \\
20,57\end{array}$ & $\begin{array}{c}141,67 \pm \\
38,72\end{array}$ & $\begin{array}{c}56,22 \pm \\
15,37\end{array}$ & $\begin{array}{c}23,26 \pm \\
8,89\end{array}$ & $\begin{array}{c}76,74 \pm \\
8,89\end{array}$ \\
\hline
\end{tabular}

$\pm \mathrm{SD}(\mathrm{n}=10)(\mathrm{P} \leq 0,05)$

Based on Table 3, it could be concluded that, the nursery trays of Sida can suitable method to grow strong healthy transplant for the industrial plantation purposes. As we expected, the double plants were smaller. The moisture content changed normally, decrease among the time progress. The double plants dry material content was higher than single plants. This phenomenon thanks to the less water support, which result from the high plant density, in that way that plant can not take up as amount of water than the single plants.

Table 3. Preliminary data of Nurse Tray-Method

\begin{tabular}{|c|c|c|c|c|c|c|c|}
\hline $\begin{array}{c}\text { Date of sample } \\
\text { collecting }\end{array}$ & & $\begin{array}{c}\text { Shoot weight } \\
\text { (with leaves) } \\
(\mathrm{g})\end{array}$ & $\begin{array}{c}\text { Height } \\
\text { of Shoots }\end{array}$ & $\begin{array}{c}\text { Rooth weight } \\
(\mathrm{g})\end{array}$ & $\begin{array}{c}\text { Number } \\
\text { of leaves }\end{array}$ & $\begin{array}{c}\text { Moisture content } \\
\text { of root }(\%)\end{array}$ & $\begin{array}{c}\text { Moisture } \\
\text { content of shoot } \\
(\%)\end{array}$ \\
\hline \multirow{2}{*}{2013.04 .30} & Single plants & $4,14 \pm 2,10$ & $29,80 \pm 1,48$ & $2,51 \pm 0,96$ & $5,60 \pm 1,14$ & 92,34 & 94,21 \\
\cline { 2 - 8 } & Double plats & $2,46 \pm 0,87$ & $25,70 \pm 5,79$ & $2,89 \pm 0,69$ & $4,10 \pm 0,74$ & 89,3 & 91,02 \\
\hline \multirow{2}{*}{2013.05 .17} & Single plants & $5,21 \pm 0,80$ & $45,20 \pm 4,32$ & $2,25 \pm 0,38$ & $5,60 \pm 0,89$ & 87,72 & 86,37 \\
\cline { 2 - 8 } & Double plats & $3,23 \pm 2,18$ & $30,90 \pm 11,70$ & $4,12 \pm 1,55$ & $4,30 \pm 0,95$ & 85,34 & 82,79 \\
\hline
\end{tabular}


In many experiments the maximum number of germinating seeds was about $30-40 \%$. For this reason, this plant actually is reproduced mainly by vegetative way in Europe (Chudik et al., 2010). During these experiments it has been found, that the success of the Sida germination shows correlation not just with the amount of the endogenous and/or exogenous fungi infections / contaminations, but their special weight and/or water imbibation / permeable characteristic. By the influence of these recognitions we modified our seed priming technique, in such a way that we fractionated the seeds based on their relative density (filtering out the floating supernatant seeds from distilled water) before we executed the treatment. The hot water treatment (HWT) was performed on the dipped / sunk seeds after separation; therefore we were able to reach $80 \%$ germination in Petri-dishes under laboratory conditions $\left(26^{\circ} \mathrm{C}\right.$ without lighting). This method is named as FSPT (floated seed priming technique). However, in our germination tests, utilizing $80 \%$ of separated and scarified seeds collected from Debrecen can germinate, against our previous results in which the germination reached at maximum $46 \%$ by HWT method.

Therefore, we can reduce the amount of sowing-seed requirements in case of Sida hermaphrodita from 200.000 300.000 seeds ha ${ }^{-1}$ to $20.000-30.000$ seeds ha-1 . Because of deficient knowledge of Sida pathological background, the farmers who planting Sida from root cuttings are confronted by considerable risk of human health and the hazard of environment. According to our opinion it has to give preference to propagation from seeds that from root cuttings. This study may indicate that the varieties take different trends in behaviour of storage ability and this refer to differences in genetic character beside environmental and agriculture pre-harvest treatment. From the investigations presented in this work, it could not be concluded clearly that the features observed during the investigated stage of $S$. hermaphrodita seeds have physical or physiological dormancy, or both. Nonetheless, it should be cleared that how can we characterize and prevent the endogenous or exogenous seed infections. It is clear that the present study is the first in the series of studies in which we plan to undertake the problem of the seed embryology of this promising energetic species.

\section{Conclusion}

From this study, it could be summarized that, this new nursery tray method of Sida from special treated seeds is a new possibility to propagate it. It is worth to mention that, the Nursery tray method, which is used in the large scale vegetable nursery can suitable method to grow strong healthy transplant for the industrial plantation purposes in this cheap industrial way.

In addition the aim of our further investigations is that we should obtain more information about seed biology of some other species of Malvaceae family (Sida hermaphrodita, Kitaibela vitifolia, Kitaibela balansae, Kitaibela x kovatsii,
Althea canabina). If we can increase the seed germination percent of different mallow species, these achievements may be new complementary material for the second (bio) generation plants within the biomass supply chain.

\section{Acknowledgement}

This research was realized in the frames of TÁMOP 4.2.4. A/2-11-1-2012-0001,,National Excellence Program Elaborating and operating an inland student and researcher personal support system convergence program" The project was subsidized by the European Union and co-financed by the European Social Fund.

\section{References}

Barthodeiszky A., Czimber Gy. (1980): A magbiológia alapjai (in Hungarian)

Baskin J. M. and Baskin C. C and Xiaojie Li (2000): Taxonomy, anatomy and evolution of physical dormancy in seeds. Plant Species Biology, 15 (2): 139-152.

Borkowska H., Molas R., and Kupczyk A. (2009): Virginia Fanpetals (Sida hermaphrodita rusby) Cultivated on Light Soil: Height of Yield and Biomass Productivity, "Polish Journal of Environmental Studies", 18 (4): 563-568.

Brouglieri M., and Liberti L. (2008): Optimal Running and Planning of a Biomass-Based Energy Production Process, "Energy Policy", 36: 2430-2438

Chudzik B., Szczuka E., Domaciuk M. and P. Danail (2010): The structure of the ovule of Sida hermaphrodita (L.) Rusby after pollination. Acta Agrobotanica, 63 (2): 3-11.

Dolinski, R. (2009): Influence of treatment with hot water, chemical scarification and storage time on germination of Virginia fanpetals, Sida hermaphrodita (L.) Rusby seeds, Buletyn Instytutu Hodowli i Aklimatyzacji Roslin, 251: 293-303.

Fári, M. (2014): Personal communication

Kaur, S., G. S. Dhillon, S. J. Sarma, S. K. Brar, K. Misra and H. S. Oberoi (2014): Waste Biomass: A Prospective Renewable Resource for Development of Bio-Based Economy/Processes. [In: S.K. Brar et al. (eds.), Biotransformation of Waste Biomass into High Value Biochemicals] pp: 3-28. DOI 10.1007/978-1-46148005-1_1, Springer Science + Business Media New York

Haraszty, Á. (1973): II Szaporító szervek. [In: Haraszty Á., Hortobágyi T., Kiss I. and Suba J.: Növénytan] 42166/1 (in Hungarian)

Kurucz, E. Fári, M.G. (2013): Relation between the germination and infection ratio on Sida hermaphrodita L Rusby seeds under hot water treatment. International Journal of Horticulture Sciences Vol 19. (1-2): 117-121.

Kurucz, E., Szarvas, P., and Fári, M.G. (2012): Alternatives of the multiple use of Virginia mallow.Acta Agraria Debreceniensis, 46: $51-57$

Pszczółkowska, A., Z. Romanowska-Duda, W. Pszczółkowski, M. Grzesik and Z. Wysokińska (2012): Biomass Production of Selected Energy Plants: Economic Analysis and Logistic Strategies. Comparative Economic Research 15 (3): 77-103.

Spooner, D. M., A.W. Cuscik, G.E Hall, and J. M. Baskin (1985): Observations on the distribution and ecology of Sida hermaphrodita (L.) Rusby (Malvaceae). Sida 11: 215-225. 